\title{
High Red Cell Distribution Width as a Biomarker of Mortality in Critically Ill Paediatric Patients
}

\section{Eva Gauchan and Sahisnuta Basnet}

Department of Paediatrics, Manipal College of Medical Sciences, Pokhara, Nepal

\section{Correspondence: \\ Eva Gauchan \\ Department of Paediatrics, \\ Manipal College of Medical Sciences, \\ Pokhara, Nepal \\ Email: evagauchan@gmail.com}

DOI: $10.3126 /$ jnps.v40i3.29596

Submitted on: 2020-06-23

Accepted on: 2020-10-04

Acknowledgements: I would like to thank Dr. Aslam Ansari for all his help in the study. I would also like to thank the patients for consenting to be a part of the study

Funding: Nil

Conflict of Interest: None declared

Permission from IRB: Yes

To cite this article: Gauchan E, Basnet $\mathrm{S}$. High red cell distribution width as a biomarker of mortality in critically ill paediatric patients. J Nepal Paediatr Soc. 2020;40(3):210-6

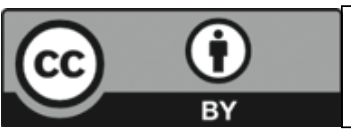

This work is licensed under creative common attribution 3.0 license

\section{ABSTRACT}

Introduction: Red cell distribution width (RDW) is a frequently overlooked parameter in routine haematological reports. It is a simple and inexpensive test which has been found by many adult studies to be a prognostic indicator of mortality in intensive care units. The objective of this study was to see if high RDW could be used as a marker to predict mortality in critically ill children.

Methods: This was a prospective observational study conducted in the paediatric intensive care unit (PICU) of a tertiary hospital of Western Nepal over a period of one year. Study subjects were selected by purposive sampling method. RDW at admission and relative change in RDW ( $\triangle \mathrm{RDW}$ ) was compared to see if they had any role in predicting mortality in this group of children. Receiver operating curve analysis was plotted to find an optimal cut-off point to define high and low RDW and various outcome parameters were analysed.

Results: Out of 131 children, there were $12(9.1 \%)$ mortalities. Admission RDW was higher in the death group as compared to the survivor group (17 vs $14.6 ; \mathrm{p}=0.012)$. Similar finding was seen with $\triangle$ RDW $(0.45$ vs $0.00 ; p=0.006) . \Delta R D W$ above the cut-off value of 0.15 was found to be associated with a generally more complicated course during hospitalisation as well as had more risk of mortality.

Conclusions: Both RDW and $\triangle \mathrm{RDW}$ above the cut-off value were found to be associated with mortality. In addition, high $\triangle \mathrm{RDW}$ was also found to predict a more complicated course during hospitalisation.

Keywords: critically-ill children; death; red cell distribution width 


\section{INTRODUCTION}

Paediatric intensive care units (PICUs) deal with critically - ill children requiring urgent medical care. Various factors can influence whether or not a child can survive beyond the critical phase. Assessment of adverse risk factors and urgency of management can help in changing the final outcome. Several scoring systems like the paediatric risk of mortality (PRISM) and paediatric index of mortality (PIM) have been used to predict the risk of a patient dying in the PICU. But these scoring systems are time-consuming and cumbersome; hence there is a need to find a simple test that can help in identifying the patients having a high risk of mortality.

Red cell distribution width (RDW) is one such test which is routinely done in all laboratories; it is inexpensive and the results can be collected within minutes. RDW is an index which reflects the variability in size of red blood cells. It is calculated by all automated haematologic analysers and is quantified as either a co-efficient of variation $(\mathrm{CV})$ or standard of deviation (SD). ${ }^{1,2}$ It has traditionally been used along with the mean corpuscular volume to differentiate the types of anaemias. ${ }^{1-4}$ But in recent years, there has been considerable interest in its use as a predictive marker of adverse outcomes in several adult diseases like autoimmune diseases, sepsis, cardiac and pulmonary diseases, operative diseases and critical illnesses. ${ }^{3-11}$ Many such studies have shown promising use of RDW as a predictive marker of mortality in adults.

In resource-limited countries like Nepal, calculating prognostic indicators like PRISM, PIM, pSOFA may be costly as well as time-consuming. RDW is a cost-effective and easy tool to predict the prognosis of critically-ill paediatric patients. Only a few studies of this type have been conducted in developing countries. ${ }^{12-15}$ As developing countries have a different health set-up as compared to developed countries, this prospective analytical observational study has been designed to find whether RDW can predict prognosis of paediatric patients in one of the tertiary centres of Nepal. The aggressiveness of management of patients can then be decided based on the predicted prognosis.

\section{METHODS}

This was a prospective, observational study conducted in the PICU of a tertiary-level hospital in Western Nepal. There were a total of 512 patients admitted to PICU during a one-year period of which we included 131 cases; this sample size was calculated taking the proportion of death in children with high RDW from a similar study conducted in India. ${ }^{14}$ All children who had low haemoglobin with iron profile studies suggestive of iron deficiency anaemia or diagnosed cases of chronic haematological disorders were excluded from the study. Similarly those cases with history of blood transfusion in last three months were excluded as these conditions might have an elevated RDW which might have an impact on our results. Those children who died or were discharged within 24 hours of admission were also excluded from the study. After taking informed consent from the guardians, patients were enrolled into the study. Ethical approval was taken from the institutional review committee prior to collecting patient's data.

Baseline demographics of the patients were noted. Course during hospitalisation was recorded. Complicated hospitalisation was defined as those cases where there were $\geq 2$ complications during hospitalisation which included status epilepticus, shock, need for mechanical ventilation, acute kidney injury, deranged liver function tests, oxygen requirement for more than 96 hours, etc. RDW was measured as a part of routine haematological test using Sysmex XN-450. For our study, we used RDW as a coefficient of variation; the reference range in our hospital was $11.5 \%-14.5 \%$. RDW was recorded in all the patients at the time of admission $\left(\mathrm{RDW}_{0}\right)$ and repeated at 48 hours $\left(\mathrm{RDW}_{48}\right) . \triangle \mathrm{RDW}$ was defined as the difference in RDW between the time of admission ( 0 hour) to repeat measurement at 48 hours of admission. It was calculated as $\Delta R D W=R D W_{48}-R W_{0}$. Other investigations were done as required.

Data were analysed by SPSS version 20. Normality was tested by Shapiro Wilk test. Quantitative data were presented as median [interquartile range] as data were non-normally distributed. Univariate analysis was done using Mann Whitney $U$ test to compare the medians of continuous non-normally 
Table 1. Patient showing characteristics at time of admission to hospital and differences between the death group and the survival group

\begin{tabular}{|c|c|c|c|}
\hline Characteristics & $\begin{array}{l}\text { Death } \\
(n=12)\end{array}$ & $\begin{array}{l}\text { Survival } \\
(n=119)\end{array}$ & $\begin{array}{c}\text { p- } \\
\text { value }\end{array}$ \\
\hline $\begin{array}{l}\text { Age in months; } \\
\text { median (IQR) }\end{array}$ & $\begin{array}{l}6 \\
(2-48)\end{array}$ & $\begin{array}{l}12 \\
(1-180)\end{array}$ & 0.172 \\
\hline $\begin{array}{l}\text { Female gender; } \mathbf{n} \\
(\%)\end{array}$ & $\begin{array}{l}3 \\
(25 \%)\end{array}$ & $\begin{array}{l}43 \\
(36 \%)\end{array}$ & 0.441 \\
\hline $\begin{array}{l}\text { Diagnosis n (\%): } \\
\text { - Infections }\end{array}$ & $\begin{array}{l}10 \\
(83.3 \%)\end{array}$ & $\begin{array}{l}92 \\
(77.3 \%)\end{array}$ & 0.631 \\
\hline - Seizure disorder & $\begin{array}{l}1 \\
(8.3 \%)\end{array}$ & $\begin{array}{l}11 \\
(9.2 \%)\end{array}$ & \\
\hline $\begin{array}{l}\text { - Poisoning } \\
\text { - Acute blood } \\
\text { disorder }\end{array}$ & $\begin{array}{l}0 \\
1 \\
(8.3 \%)\end{array}$ & $\begin{array}{l}7 \\
(5.9 \%) \\
3 \\
(2.5 \%)\end{array}$ & \\
\hline - Others & 0 & $\begin{array}{l}6 \\
(5 \%)\end{array}$ & \\
\hline $\begin{array}{l}\text { Hemoglobin in } \\
\text { gm/dl; median } \\
\text { (IQR) }\end{array}$ & $\begin{array}{l}10.2 \\
(2-11.2)\end{array}$ & $\begin{array}{l}9.7 \\
(3.1-16.9)\end{array}$ & 0.722 \\
\hline $\begin{array}{l}\text { WBC per cu.mm; } \\
\text { median (IQR) }\end{array}$ & $\begin{array}{l}17655 \\
(6960- \\
45930)\end{array}$ & $\begin{array}{l}14980 \\
(1940- \\
50000)\end{array}$ & 0.395 \\
\hline $\begin{array}{l}\text { Platelets per } \\
\text { cu.mm; median } \\
\text { (IQR) }\end{array}$ & $\begin{array}{l}211500 \\
(23000- \\
510000)\end{array}$ & $\begin{array}{l}338000 \\
(2000- \\
746000)\end{array}$ & 0.016 \\
\hline $\begin{array}{l}\text { RDW } 0 \text {; median } \\
\text { (IQR) }\end{array}$ & $\begin{array}{l}17 \\
(12-28)\end{array}$ & $\begin{array}{l}14.6 \\
(11.7-22.8)\end{array}$ & 0.012 \\
\hline $\begin{array}{l}\text { RDW }_{48} ; \text { median } \\
\text { (IQR) }\end{array}$ & $\begin{array}{l}19.2 \\
(15-29)\end{array}$ & $\begin{array}{l}14.7 \\
(10.8-32.8)\end{array}$ & 0.001 \\
\hline$\Delta R D W$ & $\begin{array}{l}0.45 \\
(0.1-8)\end{array}$ & $\begin{array}{l}0.000 \\
(-3.7-12.7)\end{array}$ & 0.006 \\
\hline $\begin{array}{l}\text { C-reactive protein } \\
\text { in } \mathrm{mg} / \mathrm{L} \text {; median } \\
\text { (IQR) }\end{array}$ & $\begin{array}{l}9 \\
(6-48)\end{array}$ & $\begin{array}{l}12 \\
(6-96)\end{array}$ & 0.511 \\
\hline $\begin{array}{l}\text { Serum ferritin in } \\
\text { ng/ml; median } \\
\text { (IQR) }\end{array}$ & $\begin{array}{l}278 \\
(39-1000)\end{array}$ & $\begin{array}{l}65 \\
(11.7-1128)\end{array}$ & 0.010 \\
\hline $\begin{array}{l}\text { Serum iron in } \mu g \text { / } \\
\text { dl; median (IQR) }\end{array}$ & $\begin{array}{l}48 \\
(12-325)\end{array}$ & $\begin{array}{l}37 \\
(2-368)\end{array}$ & 0.350 \\
\hline $\begin{array}{l}\text { Total iron binding } \\
\text { capacity in } \mu \mathrm{g} / \mathrm{dl} \text {; } \\
\text { median (IQR) }\end{array}$ & $\begin{array}{l}264 \\
(101-341)\end{array}$ & $\begin{array}{l}253 \\
(40-800)\end{array}$ & 0.604 \\
\hline
\end{tabular}

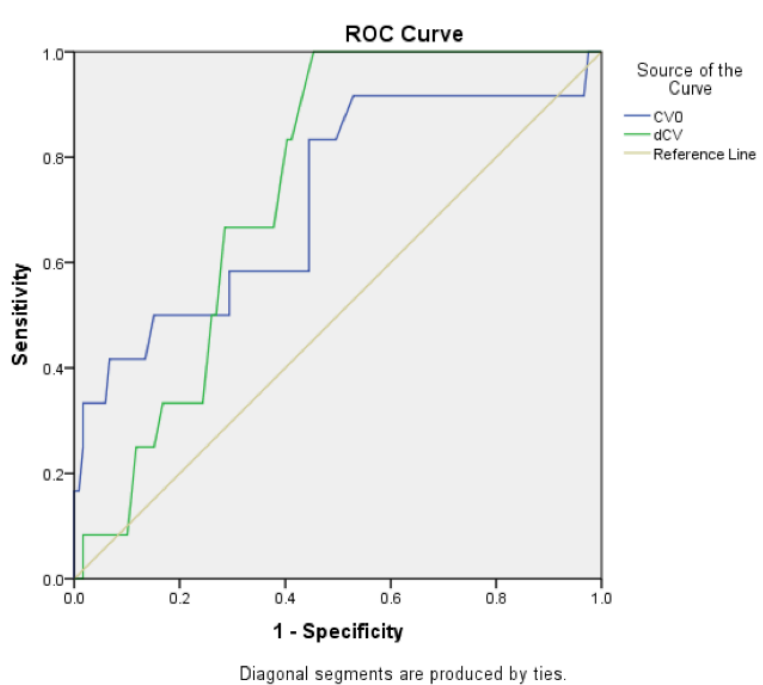

Figure 1. Receiver operating curve for $\mathrm{RDW}_{0}$ and $\triangle \mathrm{RDW}$ to predict mortality

distributed data while comparing death and survival group. Receiver operating curve (ROC) analysis was done keeping death as the static variable and was used to calculate sensitivity and specificity. Based on the ROC analysis, a cut-off value for $\mathrm{RDW}_{0}$ and $\triangle \mathrm{RDW}$ was selected with the best sensitivity and specificity. Chi-square test was used to compare the various parameters to see if higher value had a role in predicting an adverse outcome. Level of significance was taken at $p<0.05$.

\section{RESULTS}

There were total 131 patients who fulfilled the inclusion criteria of which $64.9 \%$ were males. The median age at admission to the PICU was 12 months (IQR 1 - 180). The most common indication for admission was infectious disease (102; 77.9\%) of which most common was lower respiratory tract infection $(69 ; 52.6 \%)$. The median length of stay in PICU was 72 (IQR 24 - 288) hours. The in-hospital mortality was $12(9.1 \%)$. The median $\mathrm{RDW}_{0}$ at the time of admission was 14.8 (IQR 11.7 - 28) while the median $\triangle$ RDW was 0.1 (IQR - 3.7 to 12.7). Seventy-three (55.74\%) children had $\mathrm{RDW}_{0}$ above the reference range ( $>$ 14.5) at the time of hospital admission.

Table 1 shows the demographic features of the group that died and the group that survived. The median age in the death group was lower than that in the survival group, but it was statistically 
Table 2. Showing the area under the ROC curve (AUC) with $95 \%$ confidence interval for $\mathrm{RDW}_{0}$ and $\triangle \mathrm{RDW}$

\begin{tabular}{lccrc} 
Measure & AUC & SE & \multicolumn{1}{c}{ p-value } & \multicolumn{1}{c}{$95 \%$ CI } \\
\hline RDW $_{0}$ & 0.721 & 0.085 & 0.012 & $0.554-0.888$ \\
$\Delta \mathrm{RDW}$ & 0.742 & 0.050 & 0.006 & $0.644-0.839$
\end{tabular}

insignificant $(\mathrm{p}=0.172)$. The body temperature was higher in the death group than in the survival group $(\mathrm{p}=0.043)$. The death group also had a lower systolic blood pressure as compared to the survival group $(p=0.026)$. The platelet count was lower in the death group as compared to the survival group and this finding was statistically significant $(p=0.016)$. The median $\mathrm{RDW}_{0}(\mathrm{p}=$ $0.012), \mathrm{RDW}_{48}(\mathrm{p}=0.001)$ and $\Delta \mathrm{RDW}(\mathrm{p}=0.006)$ were found to be statistically significant different between the two groups. There was also a significant difference in blood urea $(\mathrm{p}=<0.001)$, serum creatinine $(p=0.023)$, serum sodium $(p=$ $0.003)$, serum potassium $(p=0.018)$ and serum ferritin $(p=0.010)$ level between the two groups.

ROC analysis was done to generate a cut-off value to predict death for both $\mathrm{RDW}_{0}$ and $\triangle \mathrm{RDW}$ which showed a statistically significant result (Figure. 1). The AUC for $\mathrm{RDW}_{0}$ was 0.721 (95\% CI, 0.554 $0.888)$ and AUC for $\triangle \mathrm{RDW}$ was $0.742(95 \% \mathrm{CI}$ 0.644 - 0.839). Both these findings were statistically significant (Table 2).
Based on the ROC curve, a cut-off value of 14.9 for $\mathrm{RDW}_{0}$ was found to have sensitivity of $83.3 \%$ and a specificity of $55.5 \%$ for predicting death while a cut-off of 0.15 for $\triangle$ RDW had a sensitivity of $83.3 \%$ and a specificity of $59.7 \%$. Various outcome parameters were then examined based on the cutoff values in which there was a significant difference in death in those whose $\mathrm{RDW}_{0}$ was above the cut-off limit $(p=0.012)$ while other parameters were not statistically significant. In the case of $\triangle \mathrm{RDW}$, a higher value was found to have a significantly higher chances of death $(p=0.004)$, greater need of multiple inotropes $(p=0.023)$, need for mechanical ventilation $(p=0.004)$ and a more complicated hospitalisation $(\mathrm{p}=0.009)$. There was however no difference in the length of PICU stay or duration of oxygen requirement (Table 3 ).

\section{DISCUSSION}

The objective of our study was to see if RDW could be used as a marker of mortality. Our study included 131 patients of which $73(55.7 \%)$ had $\mathrm{RDW}_{0}$ above the normal reference range. There were $12(9.1 \%)$ mortalities. Our results show that RDW was higher in the group that died as compared to the survivor group. Two large community based studies in adults have found high RDW correlated with mortality. ${ }^{16,17}$ In separate studies, Zhang et al. and Luo et al. also found an association of high RDW with mortality in critically ill adult patients. ${ }^{6,18}$ Similarly several studies have been conducted on children in paediatric intensive care units which have also

Table 3. Showing relation of $\mathrm{RDW}_{0}$ and $\triangle \mathrm{RDW}$ to various outcome parameters

\begin{tabular}{|c|c|c|c|c|c|c|}
\hline \multirow[t]{2}{*}{ Parameters } & \multicolumn{3}{|c|}{$\mathbf{R D W}_{\mathbf{0}}$} & \multicolumn{3}{|c|}{$\Delta R D W$} \\
\hline & $<14.9$ & $>14.9$ & p - value & $<0.15$ & $>0.15$ & p- value \\
\hline No & $67(51.1 \%)$ & $64(48.9 \%)$ & & $73(55.7 \%)$ & $58(44.2 \%)$ & \\
\hline Need for multiple inotropes; $\mathrm{n}(\%)$ & $3(4.5 \%)$ & $1(1.6 \%)$ & 0.332 & $0(0 \%)$ & $4(6.9 \%)$ & 0.023 \\
\hline Multiple seizures; n (\%) & $13(19.4 \%)$ & $12(18.8 \%)$ & 0.924 & $12(16.4 \%)$ & $13(22.4 \%)$ & 0.387 \\
\hline Mechanical ventilation; n (\%) & $6(9 \%)$ & $6(9.4 \%)$ & 0.934 & $2(2.7 \%)$ & $10(17.2 \%)$ & 0.004 \\
\hline Complicated hospitalization; n (\%) & $21(31.3 \%)$ & $22(34.4 \%)$ & 0.712 & $17(23.3 \%)$ & $26(44.8 \%)$ & 0.009 \\
\hline $\mathrm{O}_{2}$ duration $>96 \mathrm{hrs}$ & $7(10.4 \%)$ & $9(14.1 \%)$ & 0.528 & $6(8.2 \%)$ & $10(17.2 \%)$ & 0.117 \\
\hline PICU stay $>96 \mathrm{hrs}$ & $18(26.9 \%)$ & $17(26.6 \%)$ & 0.969 & $18(24.7 \%)$ & $17(29.3 \%)$ & 0.550 \\
\hline Death; n (\%) & $2(3 \%)$ & $10(15.6 \%)$ & 0.012 & $2(2.7 \%)$ & $10(17.2 \%)$ & 0.004 \\
\hline
\end{tabular}


found an association of high RDW with mortality.5,13-15,19,20 However some other studies have found that there is no relation between high RDW and mortality in children. ${ }^{13,21}$ Said et al. also found a significant relation between admission RDW as well as relative RDW (calculated as the difference between the first day RDW and highest of the first seven days RDW divided by admission RDW) with mortality. ${ }^{19}$ Similar to our study, Khanbabaee et al. found a positive correlation between admission RDW and mortality but they could not find any association between $\triangle \mathrm{RDW}$ and mortality. ${ }^{13}$ Some studies suggest that the clearance of RBC from the circulation is well-balanced in healthy individuals but reduced in diseased states; as a result there is an increase in the number of smaller RBCs in the circulation which increases the RDW in diseased conditions. 22,23 Yčas et al. showed that hypoxia increases the secretion of erythropoietin which increases the production of large immature RBCs into the circulation which in turn increases the RDW. ${ }^{24}$ Red blood cells being extremely sensitive to oxidative stress can be hemolysed with release of immature cells into the circulation in any condition where there is production of reactive oxygen species. This leads to increased variability in RBC size. ${ }^{25}$ Dugdale et al. showed that significant disease leads to loss of control of biological processes which increases the variability of RBC sizes. They also re-affirmed the effect of hypoxia on RDW as postulated by Yčas et al. ${ }^{25,26}$ Aside from that there could be multiple other disease-specific factors like bone marrow suppression, proinflammatory cytokines and poor nutritional status which could lead to increase in anisocytosis. ${ }^{4}$ Like hypoxia, inflammation and oxidative stress have been linked as causes for the high RDW in patients who die in the intensive care units. More severe the disease condition, the higher would be the expected hypoxia and oxidative stress and hence increase in RDW. However research is going on to find out why RDW is higher in adverse conditions than in health.

High RDW as an inflammatory marker is also corroborated by a high serum ferritin which was seen in the death group. Ferritin is an acute phase reactant and high levels can be seen in any inflammatory conditions. The ferritin levels were significantly higher in the death group than in the survival group ( 278 vs 65 ; $p$-value $=0.010$ ) as seen in Table 1.

In ROC analysis a cut-off value of 14.9 for $\mathrm{RDW}_{0}$ had a sensitivity of $83.3 \%$ and specificity of $55.5 \%$ for detecting mortality while a cut-off of 0.15 for $\triangle \mathrm{RDW}$ yielded sensitivity and specificity of $83.3 \%$ and $59.7 \%$ respectively. A higher cut-off value would have increased the sensitivity of the test but compromised the specificity so we had to trade-off a lower sensitivity for a slightly higher specificity. Hence we chose a cut-off value of 14.9 and 0.15 respectively for RDW and $\triangle \mathrm{RDW}$. Outcome parameters based on the cut-off value for $\mathrm{RDW}_{0}$ showed that there was a statistically significant difference in mortality between the two groups (pvalue $=.012$ ). Similarly when we used 0.15 as a cut-off for $\triangle \mathrm{RDW}$, several outcome measures like need for multiple inotropes ( $\mathrm{p}$-value $=0.023$ ), need for mechanical ventilation ( $\mathrm{p}$-value $=0.004$ ), complicated hospitalisation $(\mathrm{p}$-value $=0.009)$ and death $(p$-value $=0.004)$ were significantly different between the high and low groups. This shows that the rate of change in RDW is more predictive of outcome than an absolute value. Several other studies have found high RDW is associated with prolonged duration of stay in PICU. ${ }^{14,15,18}$ However in our study we did not find any such association. Similar finding was seen in a study by Yanni et al. ${ }^{27}$ This most likely shows that higher values of RDW were associated with earlier mortalities so there was no relation to the duration of hospital stay. Rather it shows the relation to mortality. Same interpretation can be made for duration of oxygen requirement. With regard to need for mechanical ventilation there are conflicting findings. Schepens et al. found high RDW is associated with greater need for mechanical ventilation. ${ }^{28}$ Yanni et al. did not find any association between RDW and need for mechanical ventilation. ${ }^{27}$ In our study high $\mathrm{RDW}_{0}$ was not associated with need for mechanical ventilation but higher value of $\triangle \mathrm{RDW}$ over time was associated with need for mechanical ventilation. This shows that it is not the admission value but the rate of change in RDW that is associated with need for ventilatory support. This could mean that rate of clinical deterioration was 
more in the death group hence the need for mechanical ventilation.

There are some limitations of our study. Firstly, the sample size was relatively small and data were collected from a single centre. Secondly, the RDW is a calculated red cell parameter which expresses the heterogeneity of red cell volume in a blood sample. Given that different laboratories use different anticoagulants to inhibit blood coagulation and the difference in time taken to analyse the sample from the time of collection, the RDW value may vary between laboratories. Thirdly, different analyser machines may calculate the RDW values using different algorithms. So it would be difficult for us to generalise our results on a larger population. It would also help us better understand the predictive capability of RDW if we could have compared RDW to the known PICU mortality scoring systems.

The strong points of this study are: we excluded some confounding factors in the beginning which would have misinterpreted the results. For example we excluded those conditions in which there can be high RDW like iron deficiency anaemia, recent blood transfusion, chronic diseases etc. This helped us to be assured that the finding of high RDW was purely due to the current disease and not due to other associated factors. In addition, unlike many other studies we have also assessed the RDW change over time which showed that $\triangle \mathrm{RDW}$ would be a good marker for prognostication.

Our findings suggest that RDW could be used as a biomarker of mortality in children admitted to PICU given its easy accessibility and low cost. Also $\triangle$ RDW would have better discriminatory ability in predicting short-term outcome along with mortality prediction.

\section{CONCLUSIONS}

Our study shows that high RDW measured at the time of PICU admission is associated with mortality. It also shows that $\triangle \mathrm{RDW}$ would be a better marker of outcome than $\mathrm{RDW}_{0}$ as it shows not only the relation to mortality but also other short-term outcome measures during hospitalisation like need for multiple inotropes, mechanical ventilation, a generally complicated hospital course and mortality. We would like to recommend a similar study in a larger population to confirm our findings.

\section{REFERENCES}

1. Titcomb CP. Red cell distribution width (RDW): An under appreciated marker for increased mortality. On the risk 2017;33(1):30-46.

2. Constantino BT. Red cell distribution width, Revisited. Lab Medicine. 2013;44(2):2-9. Doi: https://doi.org/10.1309/ LMZ1GKY9LQTVFBL7

3. Badrick T. Red blood cell distribution width- a marker of fundamental importance? J Lab Precis Med. 2018;3(5). Doi: 10.21037/jlpm.2018.05.08.

4. Lippi G, Mattiuzzi C, Cervellin G. Learning more and spending less with neglected laboratory parameters: the paradigmatic case of red blood cell distribution width. Acta Biomed. 2016;87(3):323-8. PMID: 28112703

5. Safdar SA, Modi T, Sriramulu LD, Shaaban H, Sison R, Modi V, et al. The role of red cell distribution width as a predictor of mortality for critically ill patients in an inner-city hospital. J Nat Sc Biol Med. 2017;8:154-8. Doi: https://doi.org/10.4103/0976-9668.210017

6. Luo R, Hu J, Jiang L, Zhang M (2016). Prognostic value of red blood cell distribution width in non-cardiovascular critically or acutely ill patients: a systematic review. PLoS ONE 2016;11(12): e0167000. DOI:10.1371/ journal.pone.0167000.

7. Song S-Y, Hua C, Dornbors DIII, Kang R, Zhao X-X, Du X, et al. Baseline red blood cell distribution width as a predictor of stroke occurrence and outcome: a comprehensive meta-analysis of 31 studies. Front Neurol.10:1237. DOI:10.3389/fneur.2019.01237.

8. Moisă E, Negoiţă S, Corneci D. The clinical value of red blood cell distribution width as a prognosis factor and severity marker in sepsis and septic shock. Central Eur J Clin Res 2019;2(1):58-66. DOI:10.2478/cejcr-2019-0009. 
9. Braun E, Kheir J, Mashiach T, Naffaa M, Azzam ZS: Is elevated red cell distribution width a prognostic predictor in adult patients with community-acquired pneumonia? BMC Infect Dis. 2014;14:129. Doi: https://doi.org/ $10.1186 / 1471-2334-14-129$

10. Goyal H, Awad H, Hu ZD. Prognostic value of admission red blood cell distribution width in acute pancreatitis: a systematic review. Ann Transl Med 2017;5(17):342. DOI: 10.21037/atm.2017.06.61.

11. Li J, Yang X, Ma J, Gong F, Chen Q. Relationship of red blood cell distribution width with cancer mortality in hospital. Biomed Res Int 2018;8914617. DOI: 10.1155/2018/8914617.

12. Devina T, Lubis M, Mutiara E, Yanni GN, Saragih RA, Trisnawati Y, Lubis AD, Amelia P. Red cell distribution width and mortality in pediatric sepsis. Paediatr Indones 2016;56(5):320-4. Doi: 10.14238/PI56.6.2016.320-4.

13. Khanbabaee G, Hashemi SM, Salarian S, Fariborzi MR, Kiumarsi A. Red cell distribution width elevation and sepsis in pediatric critically ill patients. Arch Pediatr Infect Dis. 2018;6(2):12210. Doi: 10.5812/pedinfect.12210.

14. Sachdev A, Simalti A, Kumar A, Gupta N, Gupta D, Chugh P. Outcome prediction value of red cell distribution width in critically-ill children. Indian Pediatr. 2018;55:414-6. Doi: https://doi.org/10.1007/s13312-018-1285-5

15. Ramby AL, Goodman DM, Wald EL, Weiss SL. Red Blood Cell Distribution Width as a Pragmatic Marker for Outcome in Pediatric Critical Illness. PLoS One. 2015;10(6):0129258. DOI:10.1371/journal.pone.0129258.

16. Patel KV, Semba RD, Ferrucci L, Newman AB, Fried LP, Wallace RB, et al. Red cell distribution width and mortality in older adults: a meta-analysis. J Gerontol A Biol Sci Med Sci. 2010;65A(3):258-65. DOI: 10.1093/ Gerona/glp163.

17. Perlstein TS, Weuve J, Pfeffer MA, Beckman JA. Red blood cell distribution width and mortality risk in a community-based prospective cohort. Arch Intern Med. 2009;169(6):588-94. Doi: https://doi.org/10.1001/ archinternmed.2009.55

18. Zhang Z, Xu X, Ni H, Deng H. Red cell distribution width is associated with hospital mortality in unselected critically ill patients. J Thorac Dis. 2013;5(6):730-7. DOI: 10.3978/j.issn.2072-1439.2013.11.14.

19. Said AS, Spinella PC, Hartman ME. RBC Distribution Width: Biomarker for Red Cell Dysfunction and Critical Illness Outcome?. Pediatr Crit Care Med. 2017;18(2):134-42. Doi:10.1097/PCC.0000000000001017.

20. Gadappa SM, Behera MK. Red cell distribution width as a prognostic marker in mechanically ventilated children admitted in pediatric critical care unit of tertiary care centre, India. Int J Contemp Pediatr 2018;5:1794-800. https:// doi.org/10.18203/2349-3291.ijcp20183508

21. Meynaar IA, Knook AHM, Coolen S, Le H, Bos MMEM, van der Dijs F, et al. Red cell distribution width as predictor for mortality in critically ill patients. Neth J Med. 2013;71(9): 488-93. PMID: 24218427

22. Higgins JM, Mahadevan L. Physiological and pathological population dynamics of circulating human red cells. Proc Natl Acad Sci. 2010;107(47):20587-92. DOI:10.1073/pnas/1012747107.

23. Patel HH, Patel HR, Higgins JM. Modulation of red blood cell population dynamics is a fundamental homeostatic response to disease. Am J Hematol. 2015;90(5):422-8. DOI:10.1002/ajh.23982.

24. Yčas JW, Horrow JC, Horne BD. Persistent increase in red cell size distribution width after acute diseases: A biomarker of hypoxemia?. Clin Chim Acta. 2015;448:107-17. DOI:10.1016/j.cca.2015.05.021.

25. Ghaffari S. Oxidative stress in the regulation of normal and neoplastic hematopoiesis. Antioxid Redox Signal. 2008;10(11):1923-1940. DOI:10.1089/ars.2008.2142.

26. Dugdale AE, Badrick T. Red blood cell distribution width (RDW) - A mechanism for normal variation and changes in pathological states. J Lab Precis Med. 2018;3:73. DOI: 10.21037/jlpm.2018.08.03.

27. Yanni GN, Lubis M, Yoel C, Devina T. Association between red cell distribution width increase with severity of disease and mortality in pediatric patients with sepsis. GJRA. 2019;8(3):2277-8160. DOI: https://www.doi.org/ 10.36106/gjra

28. Schepens T, De Dooy JJ, Verbrugghe W, Jorens PG. Red cell distribution width (RDW) as a biomarker for respiratory failure in a pediatric ICU. J Inflamm. 2017;14:12. DOI:10.1186/s12950-017-0160-9. 